Literature and Society in Medieval France The Mirror and the Image 1100-1500 


\title{
Literature and Society in Medieval France
}

The Mirror and the Image 1100-1500

\author{
Lynette R. Muir
}

Macmillan Education 
ISBN 978-0-333-32558-2 ISBN 978-1-349-18029-5 (eBook)

DOI 10.1007/978-1-349-18029-5

C) Lynette R. Muir 1985

Softcover reprint of the hardcover 1st edition 1985

All rights reserved. For information, write:

St. Martin's Press, Inc., 175 Fifth Avenue, New York, NY 10010

Published in the United Kingdom by Macmillan Education Ltd First published in the United States of America in 1985

ISBN 978-0-312-48748-5

Library of Congress Cataloging in Publication Data Muir, Lynette R.

Literature and society in medieval France.

Bibliography: p.

Includes index.

1. French literature-To $1500-$ History and criticism.

2. France-History-Medieval period, 987-1515.

3. Literature and society-France. I. Title.

$\begin{array}{llll}\text { PQ151.M84 } & 1985 & 840^{\prime} .9^{\prime} 001 & 85-10901\end{array}$

ISBN 978-0-312-48748-5 


\section{Contents}

List of Plates

Acknowledgements

Guide to the Presentation of the Texts

viii

ix

$\mathbf{x}$

1 Introduction: the Mirror and the Image 1

The French Reflection 3

Rose-tinted Spectacles and Burning-glass 6

2 The Fighting Community 10

Christendom vs The Rest 11

Lord and Vassal 20

The Feud and the Family 23

(a) Raoul de Cambrai 23

(b) Renaud de Montauban 25

(c) The Romantic Epic: Ogier the Dane and Huon of Bordeaux 26

Non-combatants in the Fighting Community 27

Fact and Fantasy in the Epics: Charlemagne's Visit to Jerusalem 32

The Flawed Ideal: the Matter of Britain 35

Pagans and Aliens 40

3 The Quest of The Self 47

Springtime of Love: Chrétien de Troyes 49

Courtship and Marriage 52

Faith Unfaithful: Studies in Adultery $\quad 57$

A Woman's View-point: Marie de France 64

The Quest as Adventure: the Stories of the

Grail 68

The Language of Love $\quad 72$

The Allegory of Love: the Romance of the Rose $\quad 79$

Miracles and Marvels $\quad 81$

4 The World Upside-down 86

Hero and Anti-hero: the Knight and the Vilain $\quad 87$ 
Man and Beast: Renart the Fox

The Wheel of Fortune: Drama and the Town of Arras

A Looking-glass World: Aucassin and Nicolette

Disguise and Delusion

5 Macrocosm and Microciosm

The Image of the World

Travellers' Tales

Man the Microcosm

The Mirror of History

Man in Society

(a) The Allegory of Life

(b) The Three Estates

(c) Arts and Sciences

(d) The Mirror of Charity

Words and Pictures

6 The Gity and the Pilgrim

The Literature of Edification: Exemplary Lives of Christ and the Saints

(a) The Vernacular Bible

(b) Mother and Maiden

(c) Lives and Miracles of the Saints

Literature of Repentance

Literature of Piety and Devotion

Allegories of Salvation: Guillaume de

Deguilleville

Heaven and Hell

7 A Stage is All the World

Staging the Past: Biblical and Saints' Plays

(a) Guilds and Fraternities: the Brotherhood of the Passion

(b) 'To comb and mirror, 18d.': the Civic Plays

Staging the Present: Moralities, Farces and Sotties

(a) The King of the Basoche and the Prince of Fools 
(b) The Mirror of Folly 198

(c) Back to these Sheep: the Farce of Pathelin 202

Reality and Illusion 204

8 Inside, Outside: Man in Society 209

Mirror of France: the Hundred Years War 210

Allegories of State: the Old Pilgrim's Dream 219

One and All Alone: Christine de Pisan 224

Mirror of Women $\quad 227$

The Poet as Outsider 235

(a) Charles d'Orléans 235

(b) François Villon 239

Conclusion: the End and the Beginning 242

Appendix I: Genealogical Tables 245

Appendix II: Suggestions for Further Reading and Notes 247

Appendix III: List of Modern English Translations 253

Appendix IV: Bibliographical Index 256 


\section{List of Plates}

1. William prepares to capture Nîmes with barrel-loads of armed knights. (C) British Library.

2. Lancelot forces his way into Guinevere's bed-chamber with her permission. (C) British Library.

3. The secular clergy were often on very friendly terms with their parishioners. (C) Bibliothèque de l'Arsenal, Paris.

4. The world is round, like an apple, with all matter falling towards the centre. (C) Bibliothèque de la Ville de Rennes.

5. Even at the bottom of the sea, Alexander discovers the strong preying on the weak. (C) British Library.

6. Alexander is raised to new heights by a team of gryphons. (C) British Library.

7. This mirror offers the ladies a warning image of what they will one day become. (C) Herzog August Bibliothek, Wolfenbüttel, Germany.

8. The Pilgrim nearly falls into the clutches of Avarice. (C) British Library.

9. The sots construct their ideal world on very insecure foundations. (C) Helen Taylor. Based on photographs of the Liège production.

10. With his wife's help, Pathelin makes delirious fun of his creditor, the gullible draper. (C) The Medieval Players. 


\section{Acknowledgements}

This book grew out of a discussion with the late Denis Bethell on the relationship between literature and history and the benefits that might accrue from more wide-ranging and general exchanges of ideas and information between scholars working in the two disciplines.

The preparation of such a book would have been impossible without the help and advice of many people. First and foremost I would like to recall with gratitude the contribution of Denis Bethell himself; his breadth of interest, love of literature and ability to cite the most recondite texts was a constant stimulus and joy to his friends in other fields of study.

I would also like to express my sincere gratitude to his successor as General Editor of the series, Dr Maurice Keen, who has been most helpful in presenting the historian's view-point and most patient with my many questions; and to Sarah Mahaffy, Vanessa Peerless and Valery Rose of Macmillan for their assistance and interest.

Many of my colleagues at Leeds and elsewhere have made suggestions, answered questions or provided references; Elizabeth Williams and Gwilym Rees have been most helpful in checking the typescript and the proofs; Barbara Gill typed the Genealogical Tables, Jenifer Fairpo compiled the Bibliographical Index. The Medieval Players provided me with the photograph of the Farce of Pathelin and Madame Jeanne Wathelet-Willem of the University of Liège went to considerable trouble to make available to me photographs of the sottie; I am most grateful to all of them.

But for the help of so many people, there would be many more errors of omission and commission in this book. For those that remain the fault and the responsibility are mine. Mea culpa. 


\section{Guide to the Presentation of the Texts}

All the works referred to in this volume are identified by English titles with the original French given, once only, in parentheses. Quotations have a reference title in parentheses after them, either the author or, where appropriate, a short form of the title, normally the English one. Sometimes, however, the French version is used to avoid confusion between, for example, the many Mirrors, or to facilitate reference to the entries in Appendix IV.

No secondary literature is quoted but suggestions for further reading are given with the notes to each chapter (Appendix II). Appendix III is a list of modern English translations of medieval French texts and Appendix IV comprises an alphabetically arranged Bibliographical Index of all the medieval French texts cited, with a selection of other topics and references. Bibliographical sources for the editions used are also included.

As many of the works discussed in the book are not available in English, all quotations have been translated direct from the original French and the volume, page and line references are to the French editions. With very few exceptions the translations are in prose. In addition to the normal abbreviations, the letter ' $\mathrm{S}$ ' indicates a paragraph, section, laisse or chapter. Verse references are given without any preceding letter, for example (567-8). Biblical quotations are translated from the Vulgate. 